\title{
Saline Stress and Cell Toxicity Evaluation Using Suspended Plant Cell Cultures of Horticultural Crops Grown in a Bioreactor
}

\author{
M.E. Lima-Costa, A.L. Ferreira, A. Duarte and J. Beltrão \\ Algarve University, Unidade of Agricultural Sciences and Technologies \\ Campus de Gambelas, 8000 Faro, Portugal
}

Keywords: Salinity, citrus, plant cell suspension culture, salt tolerance, bioreactor

\begin{abstract}
Crop salt damage consists, usually, of leaf burn and defoliation, and it is associated with accumulation of toxic levels of sodium and/or chloride in leaf cells (Storey and Walker, 1999). The cell and tissue culture are simple biological systems that offer a direct approach to the metabolic changes. The plant cell growth in a controlled environment, as a bioreactor, is a unique tool for cell ion transport studies.

Cell suspension culture of citrus cell line was exposed to a medium containing different sodium chloride concentrations $(0 \mathrm{mM}, 42.7 \mathrm{mM}$ and $85.5 \mathrm{mM})$. The growth profile of control cells (absence of $\mathrm{NaCl}$ ) and $85.5 \mathrm{mM}$ cells were similar. The lack of inhibition of biomass accumulation, of all tested saline conditions clearly showed that the level of $\mathrm{NaCl}$ concentration used was not toxic for the cell metabolism. Also its ability to resist to $85.5 \mathrm{mM} \mathrm{NaCl}$ can be on evidence that this suspension cell culture might have salt tolerance characteristics.
\end{abstract}

\section{INTRODUCTION}

Since salinity is an important factor in limiting crop productivity in arid and semiarid areas of the world, the study of salt tolerance related to growth and their adaptive mechanisms to osmotic stress are among prior aims of plant scientists.

Citrus is a major horticultural crop worldwide and it is rather sensitive to salinity. Crop salt damage consists, usually, of leaf burn and defoliation, and it is associated with accumulation of toxic levels of sodium and/or chloride in leaf cells (Storey and Walker, 1999). Salinity imposes two stresses on plant tissues: a water-deficit that results from the relatively high solute concentrations in soil; and ion-specific stresses resulting from the altered $\mathrm{K}^{+} / \mathrm{Na}^{+}$ratios and $\mathrm{Na}^{+}$and $\mathrm{Cl}^{-}$ions concentrations (Blumwald et al., 2000).

In recent years, cell cultures have served as a very precious tool in trying to elucidate mechanisms of salt tolerance, operating at the cellular level. Cells in culture are simple and important systems that offer a direct approach to the changes in cell metabolism, and in the growth kinetics which can indicate adaptive mechanisms related to salt tolerance. There are few reports on the effects of salinity on cell metabolism for tissues cultured in vitro (Ben-Hayyim and Kochba, 1983; Piqueras et al., 1994; Uno et al., 1996). The potential advantages of cell culture techniques for cellular mechanism studies on salinity can be summarized as characterization of cellular mechanism involved in plant survival under salt stress conditions; selection of salt tolerant plants through screening of salt tolerant cell line; potential evaluation of germplasm tolerance to salt stress and discrimination between cellular response to salinity and tissue-specific reactions which requires organized structure at the whole plant level.

The citrus cultivar "Carvalhal" is presumed to be a natural hybrid between sweet orange and mandarin (tangor), but referred by Hodgston (1967) as of Portuguese origin. This cultivar has commercial importance in Portugal, and it was used in cross-breeding work to obtain new early-ripening hybrids.

In the present work, the resistance of "Carvalhal" tangor cell line to different $\mathrm{NaCl}$ concentrations $(42.7 \mathrm{mM}$ and $85.5 \mathrm{mM})$ was studied. We also reported the interrelations features among sodium, potassium and chloride ion mobility and their metabolic effects in order to approach the understanding of salt tolerance. 


\section{MATERIALS AND METHODS}

\section{Plant Material and Cell Culture Conditions}

Cell suspension cultures of Citrus sp. cv. "Carvalhal" were obtained by embryogenic and friable callus at a stationary phase. Calluses and suspension cells were subcultured monthly and weekly, respectively. The cell suspension cultures were maintained in an orbital agitator at 120 r.p.m and at $25^{\circ} \mathrm{C}$ in the dark. The basal medium was Murashige and Tucker Medium (Murashige and Tucker, 1969) supplemented with kinetin $1 \mathrm{mg} \mathrm{l}^{-1}$ and malt extract $0.5 \mathrm{~g} \mathrm{l}^{-1}$. Sodium chloride was added directed to the basal medium at concentrations of $42.7 \mathrm{mM}$ and $85.5 \mathrm{mM}$.

\section{Cell Growth Experiments}

Experiments were performed in $500 \mathrm{ml}$ shake flasks and initiated with a homogenized inoculum ( $20 \%$ of total volume) taken at the late linear phase of growth. Fresh weight $(\mathrm{FW})$ was determined on cells collected and vacuum filtered on Whatman No 2 filter paper. Dry weight was determined after drying the cells at $80^{\circ} \mathrm{C}$ for 48 hours. Electrical conductivity (EC) and $\mathrm{pH}$ were also monitored during the period of growth. Experiments were carried out in triplicate, each value showing the average of the three replicates.

Soluble proteins were determined according to Bradford (1976), using crystalline bovine serum albumin, as the standard. Phenol content was estimated by using the method of Anselmo et al. (1985).

\section{Determination of Ion Concentrations}

The supernant of cell filtration was used to determine ion content. Sodium and potassium cations were determined by a 410 Corning flame photometer. Chlorine anion was determined with Chloride Electrode type 152133000.

\section{RESULTS}

Cell growth was compared during 14 days, between the Na-0 cells as control (absence of $\mathrm{NaCl})$, the $\mathrm{Na}-2.5$ cells $(\mathrm{NaCl} 42.7 \mathrm{mM})$ and the $\mathrm{Na}-5$ cells $(\mathrm{NaCl} 85.5 \mathrm{mM})$. These cells (Na-2.5 and Na-5 cells) had received a salt shock, as they have been transferred into the medium containing $\mathrm{NaCl}$, at the already mentioned concentrations. The fresh and dry weight profiles of the Na-2.5 cells showed higher growth rates than that of the Na-0 cells control (Fig. $1 \mathrm{a}, \mathrm{b}$ ). The percentage of DW gain of Na-2.5 cells was about 7-fold higher than the control cells at the end of growth phase. (Fig.1 c). The pattern of the increases in $\mathrm{Na}-0$ cells and $\mathrm{Na}-5$ cells were similar. This was also shown by the specific growth rates and the biomass productivity values determined for the performed salinity experiments (Table 1). The biomass productivity is about 1.3-fold higher, for the Na-2.5 cells, than that for the control assay or for the Na-5 cells. In both control and saline conditions, (Na-0, Na-2.5 and Na-5 cells), the $\mathrm{pH}$ and the electrical conductivity variation showed similar profiles during the growth period (Fig. 2 a, b).

The accumulation in the intracellular contents of total soluble protein and phenols during the growth has also shown no significant differences among the different salt concentrations (Fig. $3 \mathrm{a}, \mathrm{b}$ ).

During lag phase, until the $4^{\text {th }}$ day, there was a sodium ion uptake from the extracellular medium and between the $4^{\text {th }}$ and the $10^{\text {th }}$ days, there was a sodium ion extrusion for Na-2.5 and Na-5 cells (Fig. 4 c). The cell growth of the control has shown a slight variation in sodium during the time period of growth.

Fig. 4 a shows the extracellular chlorine profile for different growth conditions (Na-0, Na-2.5 and Na-5 cells). At any case there was a balanced ion equilibrium until the $4^{\text {th }}$ day and an exponential accumulation up to the $8^{\text {th }}$ day only for $\mathrm{Na}-2.5$ and $\mathrm{Na}-5$ cells. During the stationary growth phase, the chlorine anion was taken up into the cells (Na-2.5 and $\mathrm{Na}-5$ cells).

The effect of $\mathrm{NaCl}$ on the medium did not reflect any particular response on 
potassium cation mobility. However, the media concentration level of potassium cation on the extracellular medium of $\mathrm{Na}-5$ cells was much lower than in the medium of control cells (Fig. 4 b).

\section{DISCUSSION}

Citrus cv. "Carvalhal" cell line maintained in a medium containing $47.2 \mathrm{mM} \mathrm{NaCl}$ ( $\mathrm{Na}-2.5$ cells) grew better than the cells grown in the absence of $\mathrm{NaCl}$ ( $\mathrm{Na}-0$ cells). Mimura et al. (1997) referred that seedling calluses grow better in the presence of $\mathrm{NaCl}$ at a level of $100 \mathrm{mM}$ than in its absence. The same was observed for sugar beet cultures (Blumwald and Pool, 1987). Since cytoplasmic sodium and chloride ions are considered toxic for the plant cell (Ben Hayyim and Kocha, 1983; Piqueras et al., 1996), the lack of inhibition of biomass accumulation of all saline tested conditions (Na-0, Na-2.5 and Na-5 cells) showed that "Carvalhal" tangor cell line was able to resist to $85.5 \mathrm{mM} \mathrm{NaCl}$, and it is likely that it can be adapted to low $\mathrm{NaCl}$ concentration $(42.7 \mathrm{mM})$. This fact suggests that this suspension cell culture possesses salt tolerance characteristic.

No great differences in protein contents were found during the cell growth phase which is a strong indication that the protein metabolism has not been changed by different salt shock.

The phenol biosynthesis is correlated with the protein pathway through a common precursor compound, phenylalanine that promotes the regulation between both pathways. When the plant secondary metabolism is activated by any biotic or abiotic stress, the phenol contents are usually drastically increased and protein biosynthesis, normally are decreased (Sahai and Shuler, 1984), and this fact has been often considered as a cell response to unhealthy cell growth conditions. Since it was observed that phenol concentration remains unchanged during the growth phase of Citrus sp. cv. "Carvalhal", it suggests that the level of $\mathrm{NaCl}$ concentration is not toxic for the cell metabolism.

From all the aforementioned results, it can be concluded that the levels of $\mathrm{NaCl}$ used in this work $(42.7 \mathrm{mM}$ and $85.5 \mathrm{mM})$ are not pernicious for the Citrus sp. cv. "Carvalhal" cell line, according to the fact that no toxicity signs could be identified.

\section{Literature Cited}

Anselmo, A.M., Mateus, J.M., Cabral, S. and Novais, J.M. 1985. Degradation of phenol by immobilized cells of Fusarium flociferum. Biotech. Let. 7 (12): 889-894.

Ben-Hayyim, G. and Kochbba, J. 1983. Aspects of salt tolerance in a NaCl selected stable cell line of Citrus sinensis. Plant Physiol. 72: 695-690.

Blumwald, E. and Poole, R.J. 1987. Salt tolerance in suspension cultures of sugar beet. Plant Physiol. 83: 884-887.

Blumwald, E., Aharon, G.S. and Apse, M.P. 2000. Sodium transport in plants. Biochimica et Biophysica Acta 1465: 140-151.

Bradford, M.M, 1976. A rapid and sensitive method for the quantification of microgram quantities of protein utilizing the principle of protein dye binding. Anal. Biochem. 72: 248-254.

Hodgston, R.W. 1967. Horticultural Varieties of Citrus. p. 431-591. In: W. Reuther, L.D. Batchelor and Webber (eds.), The Citrus Industry. Vol.1, Univ. Calif. Div. Agr. Sci. Berkeley. U.S.A.

Mimura, T., Mimura, M., Washitani-Nemoto, S. and Siripatanadilok, S. 1997. NaCldependent growth, ion content and regeneration of calluses initiated from the mangrove plant, Brugiera sexangula. J. Plant Res. 110: 31-36.

Murashige, T.D. and Tucker, H.P. 1969. Growth factor requirements of Citrus tissue culture. Proceedings of the First International Citrus Symposium, Vol 3, University of California, Riverside, pp. 1151-1161.

Piqueras, A., Olmos, E. and Hellín, E 1994. Cytological changes related with salt tolerance in embryogenic callus of Citrus limon. Plant Cell, Tissue and Organ Culture 39: 13-18.

Piqueras, A., Hernandez, J.A., Olmos, E., Hellín, E. and Sevilla F. 1996. Changes in 
antioxidant enzymes and organic solutes associated with adaptation of citrus cells to salt stress. Plant Cell Tissue and Organ Culture 45: 53-60.

Sahai., O.P. and Shuler, M.L. 1984. Multistage continuous culture to examine secondary metabolite formation in plant cells: Phenolics from Nicotiana tabacum. Biotech. Bioeng. XXVI: 27-36.

Storey, R. and Walker, R.R. 1999. Citrus and Salinity. Scientia Horticulturae 78: 39-81.

Uno, Y., Kanechi, M., Inagaki, N., Taki, N. and Maekawa, S. 1996. Growth and protein profile responses in the halophyte sea aster (Aster tripolium L.) suspension-cultured cells to salinity. J. Plant. Res. 109: 409-414.

\section{Tables}

Table 1. Specific growth rates and biomass productivity determined for Citrus cv. "Carvalhal" cell line grown at different $\mathrm{NaCl}$ concentrations.

\begin{tabular}{lcc}
\hline & $\begin{array}{c}\text { Specific Growth Rate- } \mu_{\gamma} \\
\left(\text { day }^{-1}\right)\end{array}$ & $\begin{array}{c}\text { Biomass Productivity } \\
\left(\mathrm{g} \mathrm{l}^{-1} \text { day }^{-1}\right)\end{array}$ \\
\hline Without NaCl & 0.07 & 1.80 \\
$42.7 \mathrm{mM} \mathrm{NaCl}$ & 0.11 & 2.32 \\
$85.5 \mathrm{mM} \mathrm{NaCl}$ & 0.05 & 1.72 \\
\hline
\end{tabular}




\section{Figures}
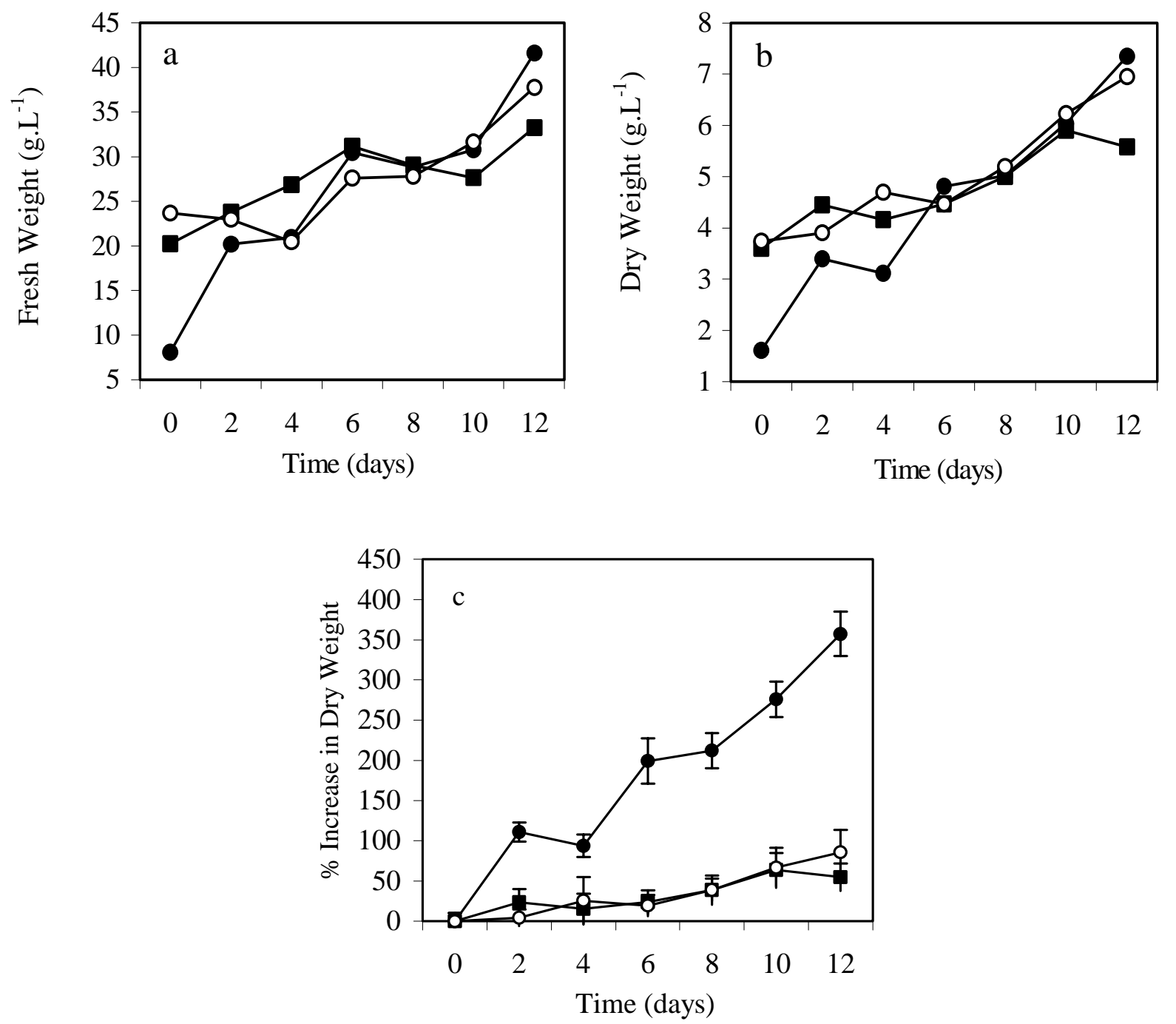

Fig. 1. Growth profiles in fresh weight (a), dry weight (b) and percentage of increase in dry weight (c) of "Carvalhal" Citrus cell line, for Na-0 cells (absence of $\mathrm{NaCl}), 2.5-\mathrm{Na}$ cells $(42.7 \mathrm{mM} \mathrm{NaCl})$ and $5-\mathrm{Na}$ cells $(85.5 \mathrm{mM} \mathrm{NaCl})$. Each value is the mean of three replicates and vertical bars represent S.D.

(匹) Na-0 cell, $(\bullet) \mathrm{Na}-2.5$ cell, $(\mathrm{O}) \mathrm{Na}-5$ cell. 

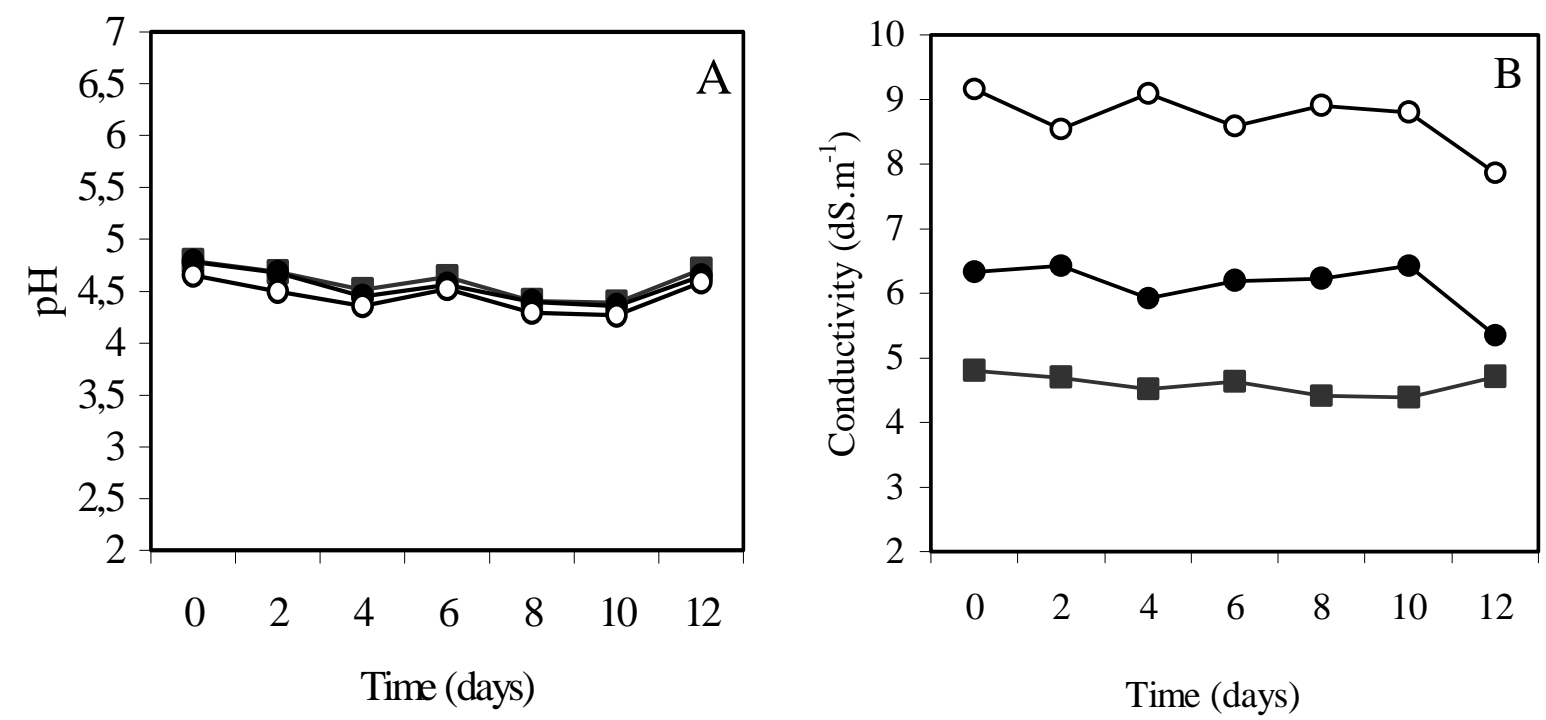

Fig. 2. pH (a) and electrical conductivity (b) variation during growth of "Carvalhal" Citrus cell line, for $\mathrm{Na}-0$ cells (absence of $\mathrm{NaCl}), 2.5-\mathrm{Na}$ cells $(42.7 \mathrm{mM} \mathrm{NaCl})$ and 5-Na cells $(85.5 \mathrm{mM} \mathrm{NaCl})$. Each value is the mean of three replicates.

$($ (ש) Na-0 cell, $(\bullet) \mathrm{Na}-2.5$ cell, $(\mathrm{O}) \mathrm{Na}-5$ cell.
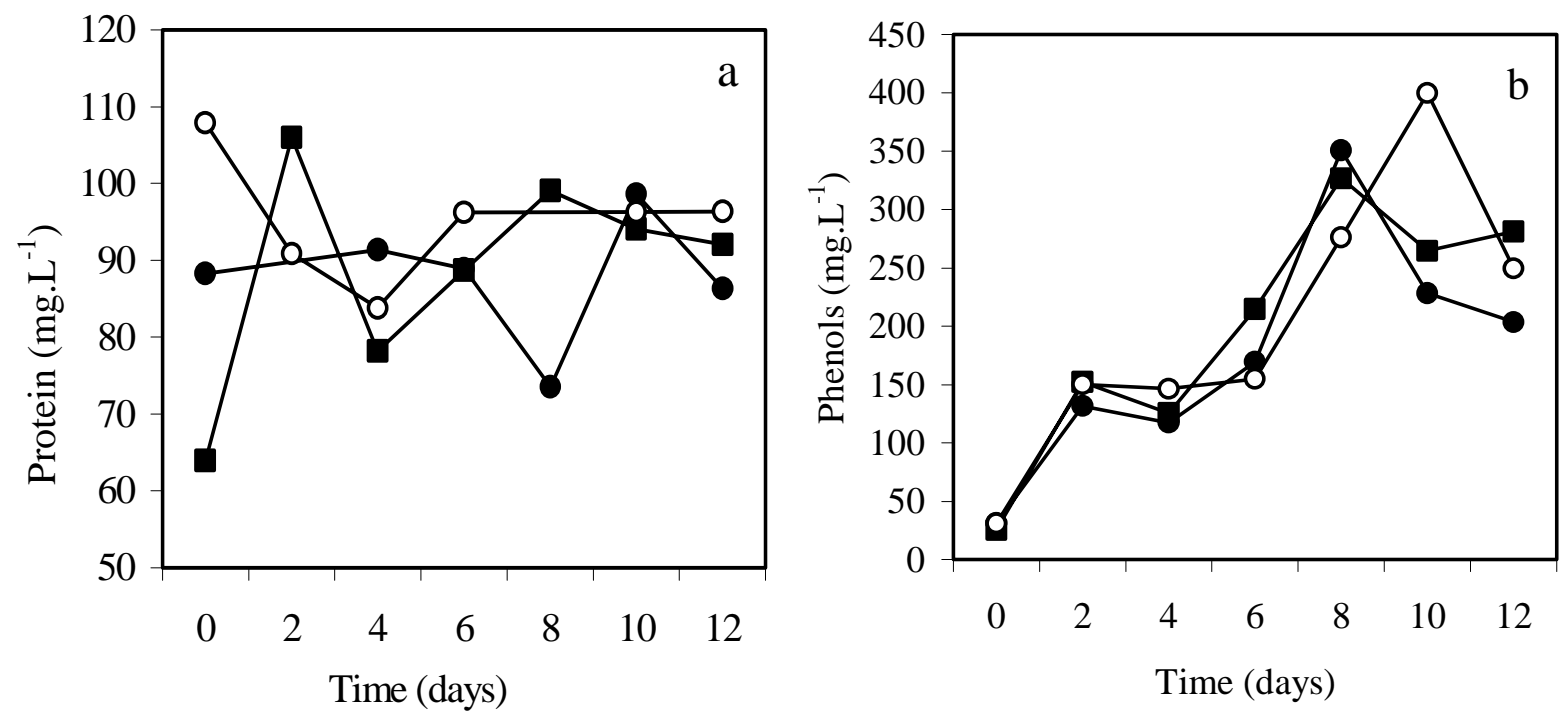

Fig. 3. Total soluble protein (A) and phenol accumulation (B) during growth of "Carvalhal" Citrus cell line, for Na-0 cells (absence of $\mathrm{NaCl}$ ), 2.5-Na cells $(42.7 \mathrm{mM} \mathrm{NaCl})$ and $5-\mathrm{Na}$ cells $(85.5 \mathrm{mM} \mathrm{NaCl})$. Each value is the mean of three replicates.

(匹) Na-0 cell, $(\bullet) \mathrm{Na}-2.5$ cell, (O) Na-5 cell. 

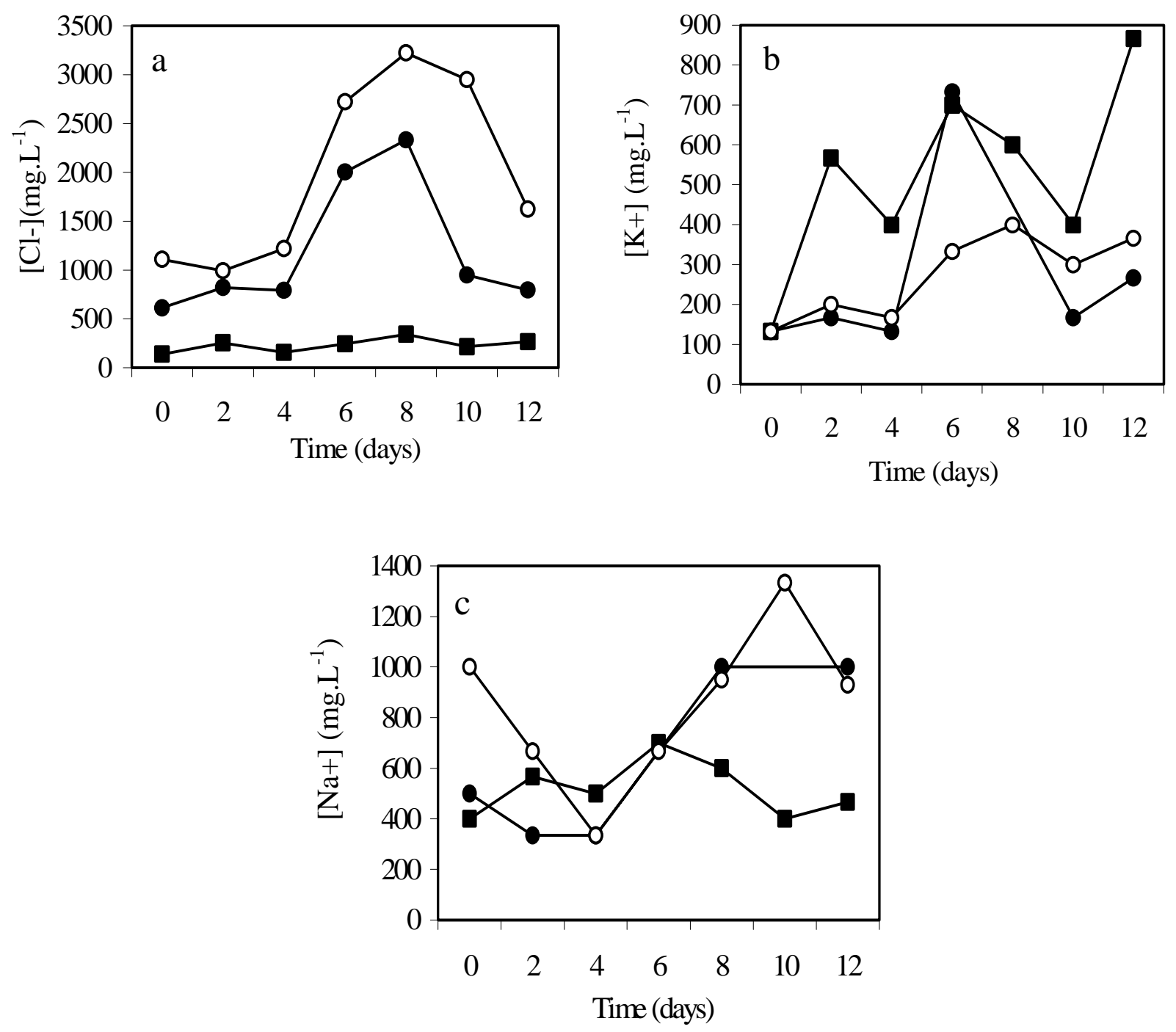

Fig. 4. $\mathrm{Cl}^{-}$(a), $\mathrm{K}^{+}$(b) and $\mathrm{Na}^{+}$(c) concentrations in supernant during growth of "Carvalhal" Citrus cell line, for $\mathrm{Na}-0$ cells (absence of $\mathrm{NaCl}$ ), 2.5-Na cells (42.7 $\mathrm{mM} \mathrm{NaCl})$ and $5-\mathrm{Na}$ cells $(85.5 \mathrm{mM} \mathrm{NaCl})$. Each value is the mean of three replicates.

(घ) Na-0 cell, $(\bullet) \mathrm{Na}-2.5$ cell, (O) Na-5 cell. 